\title{
Projektowanie procesów badawczych w zgodności z wymaganiami normy PN-EN ISO/IEC 17025:2005 z uwzględnieniem specyfiki pojazdów szynowych
}

\begin{abstract}
Aktualnie wymaga się aby procesy badawcze realizowane $w$ akredytowanych laboratoriach spetniaty wymagania normy PN-EN ISO/IEC 17025, co jest środkiem budujacym wiarygodność, powtarzalność i odtwarzalność badań. Wyniki takich badań stanowia podstawe dla oceny spetnienia wymagań $w$ procesie certyfikacji pojazdów szynowych i ich wyposażenia, dajac przestanki dla dopuszczenia pojazdu do ruchu na sieci kolejowej. W opracowaniu omówiono sposoby spetniania wymagań poszczególnych punktów normy, opatrujac je praktycznymi wskazówkami i uwagami wyniktymi z wieloletnich doświadczeń.

Opracowanie jest dedykowane przede wszystkim pracownikom badawczym $w$ branży pojazdów szynowych a także menadżerom, których świadomość specyfiki badań $i$ wymagań merytorycznych, jakościowych oraz czasowych $i$ finansowych może wplywać decydujaco na rozwój $i$ sukcesy kolejnictwa $w$ naszym kraju.
\end{abstract}

\section{Wstęp}

Przeprowadzenie badań pojazdu szynowego, jest zbiorem rozlicznych zabiegów i operacji technicznych, organizacyjnych i analitycznych, począwszy od procesu projektowania, produkcji, przygotowań i uzgodnień zakresu badań z klientem (producentem pojazdu) i jednostką dopuszczającą pojazd od ruchu. Można, zatem realizację badań uznać za proces, posiadający dane wejściowe, dane wyjściowe a między nimi poszczególne etapy i zadania zaplanowane, zdefiniowane i oceniane na bieżąco $\mathrm{w}$ trakcie realizacji. Zgodnie $\mathrm{z}$ wymaganiami normy [1], proces winien być ustanowiony przez laboratorium, udokumentowany $\mathrm{i}$ wdrożony. Ustanowienie jest zwykle uświadomieniem kontynuacji pewnych praktyk, dorobku i doświadczeń istniejących w laboratorium od lat. Udokumentowaniem procesu jest sformalizowany opis sposobu postępowania, krok po kroku z podaniem wymaganych kompetencji personelu, warunków badań, metod, niepewności pomiarów itp. Taki opis nosi nazwę procedury, opiera się na źródłowych dokumentach odniesienia (np. normach kartach UIC, Technicznych Specyfikacji Interoperacyjności, przepisach prawa) i jest zatwierdzany przez szefa organizacji - np. Dyrektora. Procedury zawieraja konkretne uregulowania operacyjne oraz dyspozycje dotyczące realizacji niezbędnych zapisów z przebiegu procesu. Dokumentowanie przebiegu każdego procesu jest jednym z najważniejszych wymagań systemowych wg normy [1] i służy zapewnieniu zasady powtarzalności i odtwarzalności działań oraz jako potwierdzenie dla jednostki akredytującej laboratorium. Działanie procesowe jest zawsze zaplanowane i nadzorowane przez osoby kompetentne, ma na celu osiagnięcie zakładanych celów, optymalizację kosztów oraz bezpieczeństwa personelu, obiektu i otoczenia podczas badań, co w przypadku tak dużych obiektów jakim jest pojazd szynowy ma pierwszoplanowe znaczenie. Proces badawczy pojazdu szynowego jest więc złożony, interdyscyplinarny i zawiera szereg segmentów zróżnicowanych pod względem wymagań i uczestników instytucjonalnych i personalnych. Zawiera w sobie wiele procedur segmentowych, nawiązujących do poszczególnych punktów normy [1].

Projektowanie procesu badawczego dla pojazdu szynowego odbywa się na dwóch przypadkach:

1) $\mathrm{W}$ ramach przygotowania laboratorium do akredytacji, opracowuje się procedury dotyczące organizacji i zarządzania laboratorium oraz procedury techniczne (badawcze, pomiarowe, metrologiczne). Określa się zakres badań akredytowanych (uznanych formalnie przez jednostkę akredytująca) oraz osoby kompetentne autoryzujące wyniki badań $\mathrm{Ca}-$ łość Systemu Zarządzania Laboratorium opisuje się w Księdze Jakości Laboratorium, która zawiera politykę i deklaracje najwyższego kierownictwa zorientowane na klienta. Księga Jakości Laboratorium jest podstawowym dokumentem - wizytówką laboratorium wobec klienta, instytucji państwowych i jednostki akredytującej. 
2) W przypadku pojawienia się zamówienia od klienta na wykonanie określonych badań, kiedy to na podstawie ustaleń $\mathrm{z}$ klientem dotyczących zakresu badań, wybiera się stosowny sposób postępowania opisany w posiadanych procedurach. Praktyka laboratoryjna wskazuje na znaczne zróżnicowanie wymagań klientów, wyboru i adaptacji metod pomiarowych, wyposażenia badawczego, warunków realizacji badań, składu osobowego ekipy oraz terminów badań. Aspekty te na etapie projektowania określonego procesu badawczego, winny być przeanalizowane, uzgodnione i udokumentowane $\mathrm{w}$ formie korespondencji, umów, potwierdzeń, harmonogramów, wycen i innych zapisów lub dokumentów. Ważnym elementem $w$ projektowaniu procesu badawczego jest współpraca niezbędnych komórek wewnątrz laboratorium i zewnętrznych, zasady komunikowania się, przekazu informacji i wyników badań oraz stanu obiektu badanego.

\section{Podejście procesowe}

Proces rozpatruje się jako ukierunkowany, uporządkowany, zaplanowany, nadzorowany i dokumentowany zbiór działań, opartych na danych wejściowych i zmierzających do osiagnięcia efektu opisanego przez dane wyjściowe. Proces winien posiadać wewnętrzne punkty kontrolne w których ocenia się skuteczność działań i decyduje o kontynuacji lub jego zatrzymaniu. Kryteria oceny procesu ustala się w oparciu o wiedzę merytoryczną i doświadczenie, co często określa się jako dobrą praktykę profesjonalną. Projektowanie wymaga dobrej znajomości wymagań i budowy pojazdów szynowych, technik pomiarowych i badawczych, kryteriów oceny wyników, wyobraźni i zmysłu organizacyjnego oraz umiejętności oceny ryzyka i pracy zespołowej. Badania pojazdu szynowego należy traktować jak proces o znacznym stopniu złożoności. Ze względów praktycznych rozdziela się go na szereg procesów prostszych, co znacznie ułatwia ich realizację. Danymi wejściowymi są zwykle wymagania Klienta, opisane w programie badań bądź przywołane z norm, kart UIC lub coraz częściej z dyrektywnych Technicznych Specyfikacji Interoperacyjności oraz obiekt badań o projektowo określonych parametrach i charakterystykach, które winny być przedmiotem badań.

Danymi wyjściowymi procesu badawczego bywa zwykle raport z badań, przedstawiający wiarygodne, obiektywne, dokładne i wyczerpujące wyniki potwierdzające lub nie, dane wejściowe. Wymienione walory wyników zawartych $\mathrm{w}$ raporcie $\mathrm{z}$ badań mają kluczowe znaczenie, ze względu na zastosowanie ich w procesie certyfikacji wyrobu a więc ocenie zgodności w aspekcie bezpieczeństwa, ekologii, komfortu jazdy itp. Kolejne kroki procesu badawczego podlegają także kontroli w celu potwierdzenia poprawności działań, utrzymania wymaganych warunków środowiskowych, wiarygodności wskazań aparatury, wyczerpania zakresu programu badań itp. Przygotowania, przebieg poszczególnych etapów procesu i jego zakończenie podlega wewnętrznej kontroli (punkty decyzyjne w algorytmie) oraz dokumentowaniu (zapisy, dokumenty).

Nie należy także lekceważyć zjawisk zakłócających skuteczność projektowania i realizacji najlepiej nawet przygotowywanych procesów badawczych. Są to potencjalnie mogące wystąpić zakłócenia, np.: przedwczesne i nieprzemyślane deklaracje stron oraz naciski na etapie oferty i umowy, zmiany w zachowaniu się stron po podpisaniu umowy, świadome lub nieświadome przekazanie do badań niekompletnego lub niesprawnego obiektu, próby przerzucania na badaczy usuwania usterek i wad obiektu, wprowadzanie zmian w obiekcie w trakcie badań, oczekiwanie sztywnej realizacji ceny i terminu badań, mimo oczywistych zakłóceń wymienionych wyżej łącznie $\mathrm{z}$ odmową zgody na aneksowanie umowy, nieakceptowanie negatywnych wyników badań, niepłacenie faktur za zrealizowane badania. Wszystkie potencjalne zakłócenia winny być świadomie uwzględniane w projektowaniu procesu badawczego.

Projektowanie procesu badawczego przebiega etapowo, uwzględniając wymagania normy PN-EN ISO/IEC 17025:2005 [1]. Poszczególne etapy projektowania krok po kroku przedstawia algorytm (arkusze $1-8)$.

\subsection{Wstępne ustalenia i zawarcie umowy $\mathrm{z}$ Klien- tem}

Rozpoczynają się z chwilą zgłoszenia przez klienta zapytania ofertowego lub potrzeby wykonania badań pojazdu szynowego lub jego części. Zwykle odbywa się to poprzez wstępną rozmowę sondażową lub informacyjna. Już na tym etapie istotne jest pierwsze wrażenie dla obu stron. Ze strony klienta padają pytania o cenę usługi i termin realizacji, także o szczegóły techniczne. Już w tym momencie warto zdawać sobie sprawę kim jest klient, jakie są jego oczekiwania, jaki jest zasięg jego działalności i czemu mają służyć wyniki badań, wreszcie jakie wymagania winien spełniać jego produkt i gdzie są one zapisane? Bez wyjaśnienia tych zagadnień trudno udzielić klientowi szybkiej i wyczerpującej odpowiedzi w formie oferty. Należy pamiętać, że pochopna i nieprzemyślana odpowiedź, zapada w świadomość klienta i określa granicę oczekiwań, której zmiany (nawet bardzo uzasadnianej później przez laboratorium) nie zawsze jest skłonny akceptować. Aby dobrze ocenić koszty i terminy badań, niezbędna jest wyczerpująca informacja o zakresie badań, i odbiorcy wyników, który na ich podstawie podejmować będzie decyzje o dopuszczeniu lub nie 
pojazdu do eksploatacji a więc o sukcesie lub niepowodzeniu finansowym klienta. Stąd wynika potrzeba wielkiej odpowiedzialności obu stron w negocjacjach. Klient nie zawsze jest $\mathrm{w}$ pełni świadom niuansów postępowania jednostek certyfikujących pojazdy szynowe i dopuszczających je do eksploatacji. Aby uniknąć nieporozumień wskazane byłoby na etapie planowania badań, zasięgać konsultacji w instytucji dopuszczającej pojazd do eksploatacji, celem precyzyjnego określenia wymagań [4]. Mogłoby to być trójstronne porozumienie uściślające poziom wymagań $\mathrm{z}$ podaniem niezbędnych dokumentów odniesienia technicznych i prawnych.

W tej sytuacji dialog pomiędzy laboratorium a klientem, jest niezbędnym elementem współpracy, która winna wyjaśniać klientowi specyficzne zagadnienia badań $\mathrm{w}$ aspekcie technicznym, organizacyjnym i doradczym w odniesieniu do pojazdu szynowego będącego obiektem badań.

Praktyka wykazuje, iż klienci cenią sobie wysoko otwartość i kompetencje laboratoriów, przez co bywają niekiedy łagodniejsi w negocjacjach cenowych i terminowych, a nie wyklucza się także wydzielenia w przyszłej umowie odrębnego zadania dotyczącego konsultacji lub porad w doskonaleniu przedmiotowego pojazdu.

Kolejnym, po etapie ofertowym jest przygotowanie umowy. Wynegocjowane ustalenia uzyskują szate formalna, przygotowaną zwykle przez Laboratorium i Dział Ekonomiczny oraz podlegają przeglądowi przed podpisaniem przez Strony. Ewentualne uwagi winny być odnotowane i zachowane w aktach tematu. Zapisy te winny być autoryzowane i datowane jako dowód przeglądu umowy. Umowa winna jednak zawierać zastrzeżenia regulujące postępowanie $\mathrm{w}$ okolicznościach zakłócających proces badawczy - losowych bądź zamierzonych przez strony lub kooperantów. Czasami korzystnie jest zawrzeć $\mathrm{z}$ kooperantami umowy dodatkowe np. na wypadek wystapienia potrzeby dokonania niezbędnych zmian lub napraw wynikłych podczas badań, w sprawie jazd badawczych na torach PKP, podwykonawcami badań uzupełniających, usługami serwisowymi itp.

Współpraca z klientem przebiega zwykle na bieżąco podczas realizacji procesu badawczego. Składają się na to: przygotowanie i przekazanie obiektu badań, zapewnienie serwisowania obiektu, dostarczenie oprzyrządowań niezbędnych do badań, uczestnictwo przedstawiciela klienta w badaniach itp.

\subsection{Realizacja ustaleń umowy $w$ zakresie specyfi- kacji badań.}

Jeżeli z umowy wynika, że należy opracować program (specyfikację) badań, to opracowania dokonuje Laboratorium uwzględniając obowiązujące normy lub inne przepisy określające kryteria i rodzaje badań, korzystając gdy to konieczne z konsultacji wyspecjalizowa- nych w danej dziedzinie specjalistów. W szczególnych przypadkach opracowanie specyfikacji badań może być ulokowane w innych komórkach Instytutu [3]. Specyfikacja jest weryfikowana, uzgadniana $z$ klientem i zatwierdzana przez kierownika komórki opracowującej. Jeżeli klient dostarcza własną specyfikację badań, to podlega ona uzgodnieniu między stronami, co jest odnotowywane na stronie tytułowej.

\subsection{Realizacja ustaleń umowy $w$ zakresie metod badawczych.}

Laboratorium stosuje standardowe metody badawcze i pomiarowe, wynikające $\mathrm{z}$ obowiązujących w kolejnictwie Norm Europejskich, Technicznych Specyfikacji Interoperacyjności lub Kart UIC. Dokumenty te zapewniają wiarygodność badań, ich powtarzalność i adekwatność porównawczą uzyskiwanych wyników. Posiada to szczególne znaczenie w przypadku wykorzystywania wyników w procesie certyfikacji wyrobów i uzyskaniu świadectwa dopuszczenia pojazdu do ruchu. W przypadku potrzeby stosowania innych niestandardowych metod, Laboratorium posiada procedurę i możliwości walidacji metody nietypowej.

\subsection{Przygotowanie planu (harmonogramu badań)}

Wykonuje specjalista prowadzący temat badawczy w oparciu o ustalenia umowy, przygotowany wcześniej program (specyfikację) badań oraz stosowne procedury badawcze i pomiarowe. Harmonogram jest weryfikowany przez kierownika pracowni i zatwierdzany przez kierownika Laboratorium.

Jeżeli zakres badań jest znaczny a wymagany przez klienta termin realizacji krótki lub ze względów obiektywnych (choroba personelu, awaria sprzętu) nie można dotrzymać terminu, albo zamówienie klienta zawiera fragmenty badań nie leżące w profilu laboratorium, wówczas zachodzi konieczność zlecenia badań u wyspecjalizowanego wykonawcy. Kierownik Laboratorium prowadzi rejestr kwalifikowanych dostawców w dziedzinie badań z którego wybiera podwykonawcę. Wybór musi być poparty posiadaniem przez Laboratorium podwykonawcy akredytacji, oraz zgodą klienta.

\subsection{Organizacja badań ruchowych}

Jeżeli zachodzi potrzeba wykonania badań ruchowych, prowadzący temat badawczy dokonuje wyboru stosownego odcinka na sieci PLK-PKP oraz uzgadnia warunki realizacji badań. Szersze omówienie badań ruchowych w tym eksploatacji obserwowanej znajduje się w [2].

$\mathrm{Na}$ tym etapie należy zwracać szczególną uwagę na bezpieczeństwo i organizację jazd oraz optymalizację kosztów przejazdów, których koszty stanowią znaczący udział w kosztach badań.

\subsection{Realizacja ustaleń umowy $w$ zakresie oprzy- rządowań badawczych.}

Jeżeli niezbędne jest wykonanie oprzyrządowania do badań (spełniającego rolę połączenia obiektu ze sta- 
nowiskiem badawczym), kierownik pracowni wyznacza osobę dla opracowania dokumentacji konstrukcyjnej. Dokumentacja jest weryfikowana przez kierownika pracowni i zatwierdzana przez kierownika Laboratorium. Kierownik Laboratorium prowadzi rejestr kwalifikowanych dostawców w dziedzinie wykonawstwa oprzyrządowań badawczych, na podstawie którego dokonuje wyboru wykonawcy. Wykonawcą może być Zakład Prototypów w Instytucie lub firma zewnętrzna. Wykonane oprzyrządowanie jest odbierane na zgodność z dokumentacją przez Dział Kontroli Jakości z udziałem autora dokumentacji. Z odbioru sporządza się protokół, który parafuje autor dokumentacji i zatwierdza kierownik Działu Kontroli Jakości.

\subsection{Opracowanie zapotrzebowań na materiały po- mocnicze}

Prowadzący temat badawczy określa potrzeby w zakresie materiałów pomocniczych niezbędnych dla prowadzenia badań i sporządza zapotrzebowanie. Szczegółowy sposób postępowania wg ogólnie stosowanych zasad.

\subsection{Przyjmowanie próbek/obiektów badań}

W przypadku gdy Laboratorium nie pobiera próbek, $\mathrm{w}$ oparciu o ustalenia $\mathrm{w}$ umowie prowadzacy temat badawczy uzgadnia szczegóły dostawy obiektu badań, środek transportu i datę oraz pilotuje odbiór dostawy przez Laboratorium. Przy rozładunku obiekt badań jest identyfikowany i rejestrowany. Jeżeli obiekt nie spełnia wymagań umowy i nie nadaje się do badań, następuje powiadomienie klienta i postępowanie wg odrębnej procedury.

\subsection{Montaż obiektu na stanowisku badawczym}

Realizuje personel Laboratorium pod nadzorem prowadzącego z użyciem środków transportu wewnętrznego (suwnica, lokomotywa manewrowa, wózek widłowy). Obiekt jest łączony ze stanowiskiem badawczym przy pomocy wcześniej wykonanych oprzyrządowań. Na tym etapie, ważne jest aby wszystkie elementy oprzyrządowań, mogące mieć wpływ na wyniki badań, były dokładnie skontrolowane i starannie zmontowane. W przypadku stosowania materiałów pomocniczych np. tensometry, klej, przewody elektryczne, są one pobierane przez personel Laboratorium na podstawie dokumentów materiałowych wystawionych przez prowadzącego i zatwierdzonych przez Kierownika Laboratorium. Szczegółowy sposób postępowania wg ogólnie stosowanych zasad.

\subsection{Montaż wyposażenia pomiarowo-badawczego na obiekcie}

Realizuje personel Laboratorium pod nadzorem prowadzącego zgodnie $\mathrm{z}$ wymaganiami procedur badawczych i pomiarowych określonych w harmonogramie badań. Przed zamontowaniem jest

sprawdzany stan i status wyposażenia zgodnie z procedurą dotyczącą nadzoru nad wyposażeniem badawczym i spójnością pomiarową.
2.11.Zabezpieczenie warunków środowiskowych i mediów energetycznych

Zgodnie $\mathrm{z}$ wymaganiami zastosowanych procedur badawczych i pomiarowych, prowadzący temat badawczy, określa niezbędne media energetyczne, sprawdza stan warunków środowiskowych i zgłasza z wyprzedzeniem potrzeby do Działu Zabezpieczenia Ruchu poprzez wpis do zeszytu potrzeb. W oparciu o zapisy $\mathrm{w}$ zeszycie, zabezpieczane są: wysokie napięcie, sprężone powietrze, woda itp. zgodnie z obowiązującymi przepisami energetycznymi i bhp.

\subsection{Uruchomienie i zgrywanie układu badawczego} Realizuje personel Laboratorium pod kierunkiem prowadzącego temat badawczy i przy współpracy pracowników Sekcji Technicznej Laboratorium. Kolejno sprawdza się i uruchamia poszczególne fragmenty układu badawczego aż do uzyskania kompleksowej gotowości do badań.

Następnie dokonuje się pomiarów kontrolnych przed badaniami, mając na celu upewnienie się, że wszystkie tory pomiarowe działaja poprawnie. $Z$ pomiarów tych dokonuje się zapisów w zeszycie prowadzącego temat. Na tym etapie należy znać wymagania Klienta lub dokumentów odniesienia, dotyczące niepewności pomiarów. Jest to wymaganie decydujące o wiarygodności wyników, szczególnie, gdy wyniki układaja się w pobliżu wartości dopuszczalnych i mogą ją przekroczyć. Wówczas o uznaniu wyniku za wiarygodny musi decydować rachunek niepewności pomiaru.

\subsection{Realizacja harmonogramu badań}

Po uruchomieniu i przetestowaniu układu badawczego, prowadzący wraz z niezbędnym personelem wykonuje badania realizując kolejne punkty harmonogramu. W trakcie badań dokonuje zapisów we wcześniej przygotowanych formularzach wymaganych przez procedury badawcze i pomiarowe, bądź wydruków i zapisów cyfrowych lub analogowych.

\subsection{Kontrola jakości wyników badań}

Podczas badań prowadzący w ramach czynności kontrolnych na bieżąco analizuje wyniki i zachowanie się obiektu dla upewnienia się czy próby przebiegaja prawidłowo. Laboratorium posiada odpowiednią procedurę i narzędzia do weryfikacji uzyskiwanych wyników, zgodnie z wymaganiami normy [2]. W przypadku stwierdzenia nieprawidłowości $\mathrm{w}$ przebiegu badań prowadzący dokonuje analizy przyczyn w celu odpowiedzi na pytanie: czy występuje wada w wyposażeniu czy też $\mathrm{w}$ obiekcie badań ? W przypadku nieprawidłowości $\mathrm{w}$ wyposażeniu, zgodnie $\mathrm{z}$ procedurą nadzoru, następuje wymiana lub naprawa wyposażenia niezgodnego, oraz zapis w zeszycie prowadzącego i w kartotece wyposażenia. W przypadku niesprawności obiektu badanego, następuje zawiadomienie klienta oraz ustalenie dalszego postępowania. 


\subsection{Ustalenie zakresu korekt i powtórzeń}

W oparciu o ustalony w porozumieniu z Klientem, sposób postępowania $\mathrm{z}$ obiektem niesprawnym oraz wyniki analizy nieprawidłowości, prowadzący ustala zakres badań jakie należy powtórzyć w związku ze stwierdzonymi nieprawidłowościami.

\subsection{Korekta harmonogramu badań i aneksowanie umowy}

Na podstawie ustalonego skorygowanego zakresu prac oraz określonego terminu wznowienia badań, prowadzący koryguje harmonogram. Dział Ekonomiczny na podstawie przygotowanych przez prowadzącego i zaakceptowanych przez Kierownika Laboratorium nowych terminów i zakresów prac przygotowuje aneks do umowy.

\subsection{Realizacja uzgodnień $\mathrm{z}$ klientem}

Jeżeli naprawa obiektu jest technologicznie możliwa i może być wykonana na terenie Instytutu, naprawy dokonuje serwis klienta zgodnie $\mathrm{z}$ ustaleniami potwierdzonymi w aneksie do umowy.

Naprawa obiektu badań może odbywać się na terenie Instytutu w celu obniżenia kosztów badań i skrócenia terminu. Jest to racjonalne ze względu na: duże gabaryty i masy obiektów, znaczne koszty transportu takich obiektów, straty czasu w transporcie, znaczne nakłady pracy na demontaż i ponowny montaż obiektów na stanowisku badawczym oraz specyficzną infrastrukturę kolejową w Laboratorium (bocznica, tory i kanały w hali badań) zasilanie wysokim napięciem i sprężonym powietrzem, suwnice, prototypownię i współpracę konstruktorską na miejscu. Dopuszcza się $\mathrm{w}$ porozumieniu $\mathrm{z}$ Klientem dokonywanie napraw obiektów na terenie Laboratorium pod ściśle określonymi warunkami: naprawy nie będą kolidować z innymi badaniami, na czas naprawy zostanie zdemontowane lub zabezpieczone wrażliwe i cenne wyposażenie pomiarowo-badawcze, teren na którym dokonuje się naprawy zostanie na ten czas wydzielony z pozostałej części Laboratorium, zostanie zachowana poufność prac i ochrona interesów klienta, osoby bezpośrednio odpowiedzialne za wyniki badań nie będą angażowane do wykonywania napraw, $\mathrm{z}$ przeprowadzonej naprawy będzie sporządzony protokół przez wykonującego naprawę.

Jeżeli nie jest możliwe postępowanie naprawcze na terenie Laboratorium, następuje zwrot obiektu do klienta celem naprawy lub wymiany. Szczegółowy sposób postępowania określają obowiązujące w Laboratorium instrukcje dotyczące warunków i sposobu transportu obiektów.

Wykonanie naprawy lub ewentualnych zmian jest potwierdzane zapisem $\mathrm{w}$ formie protokołu.

\subsection{Kontynuacje badań}

Po usunięciu wszystkich nieprawidłowości następuje wznowienie badań zgodnie podpisanym aneksem do umowy.

\subsection{Analiza wyczerpania zakresu badań}

W trakcie realizacji badań prowadzący na bieżąco analizuje rezultaty celem upewnienia się czy badania przebiegaja prawidłowo, czy wyczerpano planowany zakres badań i czy uzyskane wyniki są kompletne, miarodajne i przydatne dla opracowania raportu $\mathrm{z}$ badań.

Jeżeli nie zrealizowano całego zakresu badań określonego w umowie, badania są kontynuowane.

\subsection{Zakończenie badań}

Następuje po wyczerpaniu całości zakresu określonego umową oraz upewnieniu się, że uzyskane wyniki są kompletne, miarodajne i przydatne dla opracowania raportu $\mathrm{z}$ badań

\subsection{Demontaż wyposażenia pomiarowo-badaw- czego i zwrot obiektu}

Po zakończeniu badań wyposażenie jest demontowane przez pracowników Laboratorium oraz przekazywane do miejsca przechowywania gdzie sprawdza się stan i dokonuje zapisów w kartotekach zgodnie z procedura nadzoru nad wyposażeniem. Następnie dokonuje się demontażu obiektu ze stanowiska badawczego i przygotowuje go do transportu zwrotnego, zgodnie $\mathrm{z}$ instrukcja transportu oraz przygotowuje się dokumenty ekspedycyjne.

Wyekspediowanie obiektu po badaniach jest odnotowywane w rejestrze obiektów.

\subsection{Przygotowanie raportu $\mathrm{z}$ badań}

Obejmuje przegląd i segregację tematyczną wyników badań, obserwacji i informacji, niezbędnych dla opracowania raportu $\mathrm{z}$ badań. Realizuje specjalista prowadzący temat badawczy na podstawie poczynionych $\mathrm{w}$ trakcie badań zapisów wyników oraz w oparciu o procedurę opisującą sposób opracowywania raportu.

\subsection{Przygotowanie protokołu zdawczo-odbiorcze- go i przekazanie raportu Klientowi}

Protokół przygotowuje Dział Ekonomiczny we współpracy z Laboratorium. Wysłanie raportu i protokołu do klienta realizuje Dział Ekonomiczny zgodnie z procedurą zachowania wymagań poufności wyników badań i identyfikacji osoby odbierającej dokumenty ze strony Klienta.

\subsection{Wystawienie i wysłanie faktury do klienta}

Faktura jest wystawiana i odnotowywana w dzienniku korespondencji. Wpływ należności za wykonanie badań wg faktury podlega zapisowi w Dziale Ekonomicznym i kończy realizację tematu. Ewentualne sprawy sporne załatwiane są zgodnie $\mathrm{z}$ procedura rozpatrywania skarg i reklamacji. Rozliczenie tematu jest realizowane w Dziale Ekonomicznym w oparciu o zapisy kosztów realizacji tematu. Uzyskane dane są wykorzystywane do analiz ekonomicznych działalności Laboratorium. 


\subsection{Badanie zadowolenia klienta}

Laboratorium oraz Dział Ekonomiczny zbierają informacje pozwalające ocenić poziom zadowolenia klientów z usług badawczych. Dane te są podstawą do ewentualnych działań korygujących lub doskonalących w obszarze współpracy z Klientem.

\section{Podsumowanie}

3.1.Ze względu na rosnące wymagania Klientów w obszarze realizacji badań pojazdów szynowych a co za tym idzie skracania terminów i obniżania kosztów, proces badawczy pojazdu szynowego powinien być dobrze przygotowany, optymalny i niezawodny.

3.2.Dostępna aktualnie aparatura badawcza o dużym stopniu integracji i niezawodności daje duże możliwości projektowania i realizacji złożonych procesów badawczych.

3.3. Wysokie wymagania w odniesieniu do procesów badawczych obligują laboratoria do precyzyjnego planowania badań, co można osiagnąć poprzez projektowanie udokumentowanych procesów dla poszczególnych rodzajów badań. Jest to jednocześnie spełnianie wymagań normy PN-EN ISO/IEC 17025:2005 [1], będącej podstawą bardzo już rozpowszechnionej akredytacji Laboratoriów.

3.4.Poszerzenie i upowszechnienie wiedzy o specyfice badań pojazdów szynowych wśród pracowników a także menadżerów w branży, stwarza możliwości, że świadomość tej specyfiki oraz wymagań merytorycznych, jakościowych, czasowych i finansowych może wpływać decydująco na harmonijny rozwój i sukcesy kolejnictwa $\mathrm{w}$ naszym kraju.

\section{Literatura}

[1]. PN-EN ISO/IEC 17025:2005 - Ogólne wymagania dotyczace kompetencji laboratoriów badawczych $i$ wzorcujacych.

[2]. Tarczewski R.: Badania eksploatacyjne pojazdów szynowych ważnym obszarem pracy laboratorium IPS „TABOR”.

[3]. Tarczewski R.: System Jakości stosowany w IPS „TABOR” $i$ kompetencje techniczne gwarancja utrzymania wiarygodności wspótpracy z klientami.

[4]. Tarczewski R.: Certyfikacja pojazdów szynowych narzędziem spetnienia wymagań bezpieczeństwa i interoperacyjności.

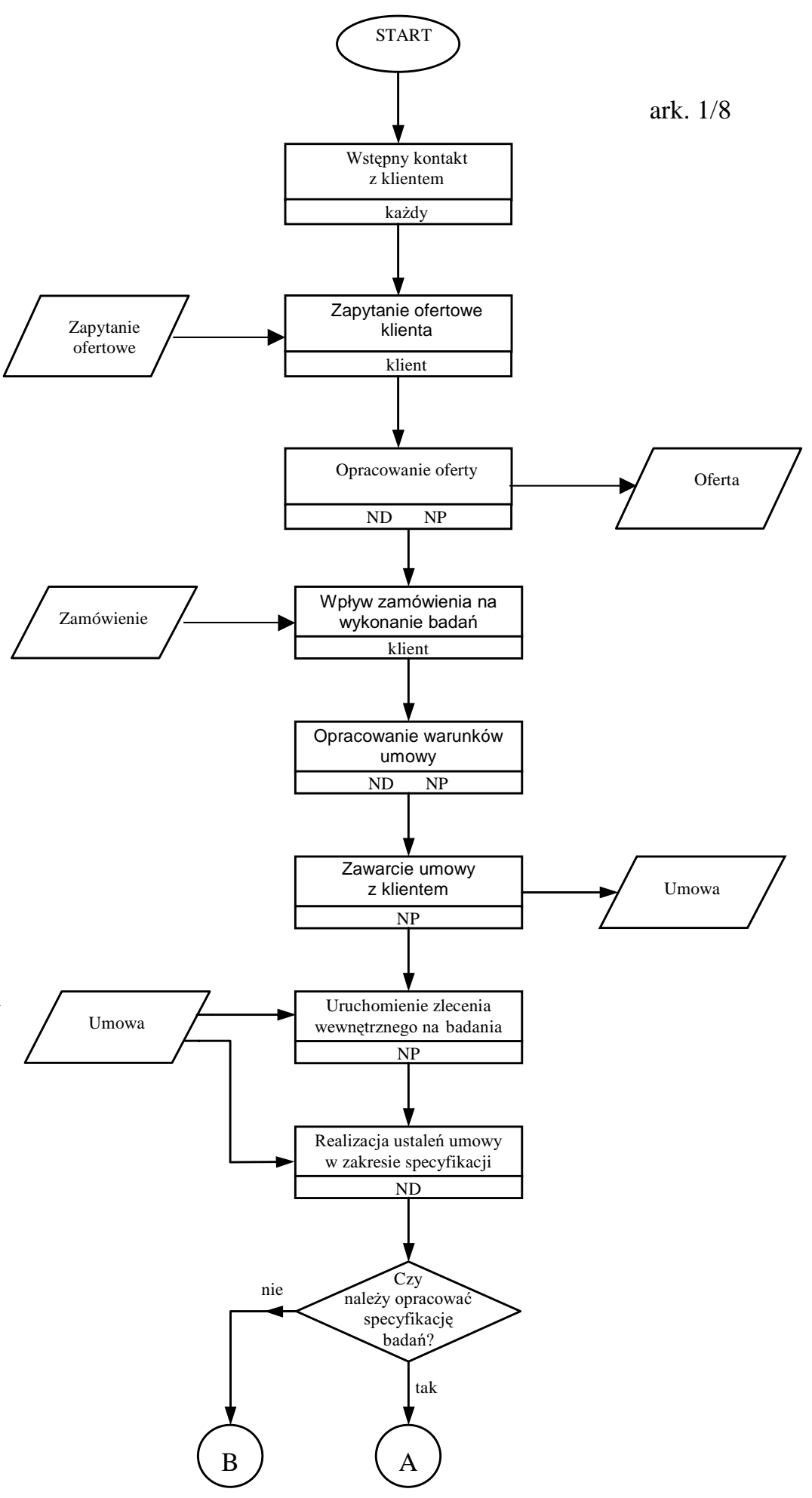



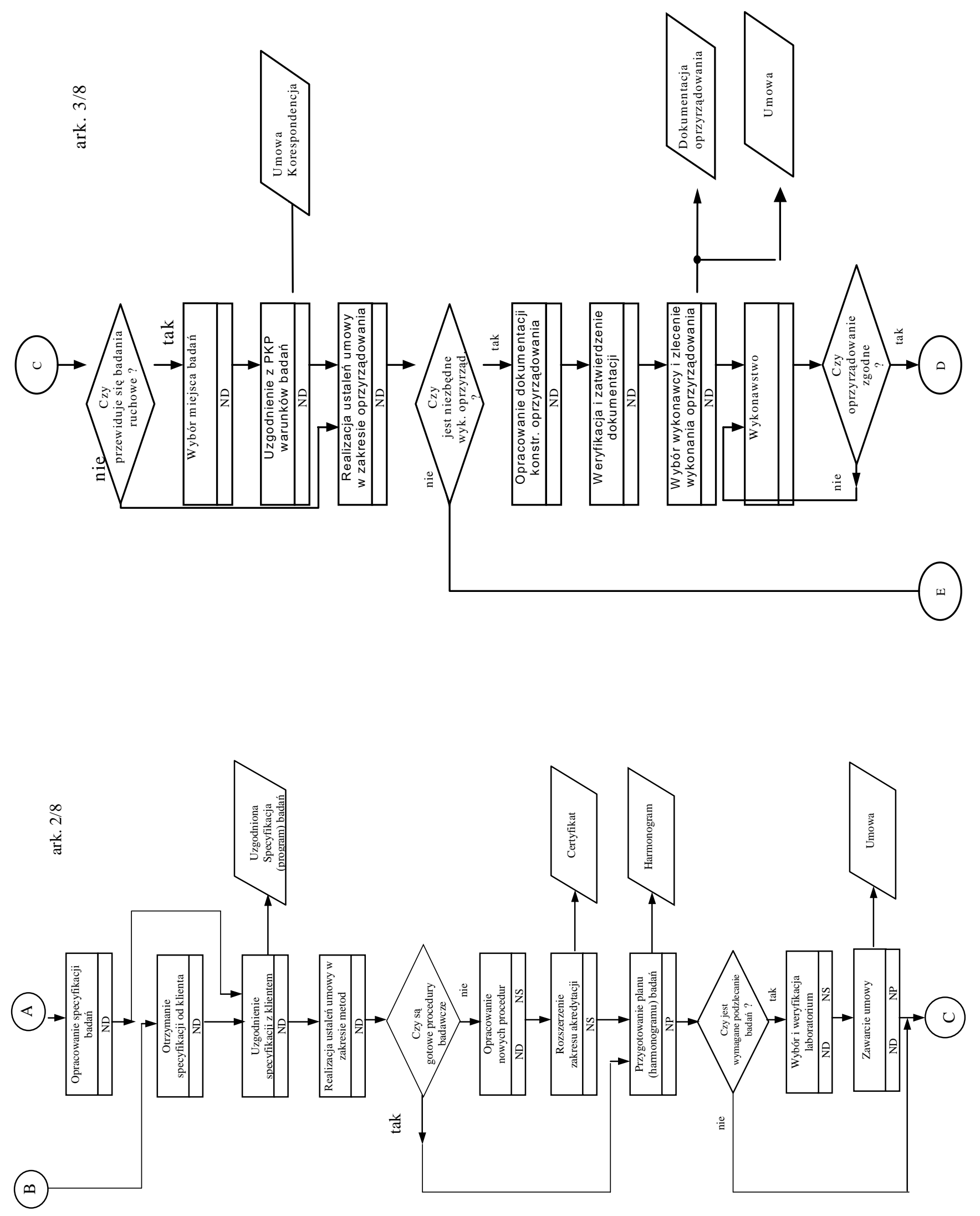

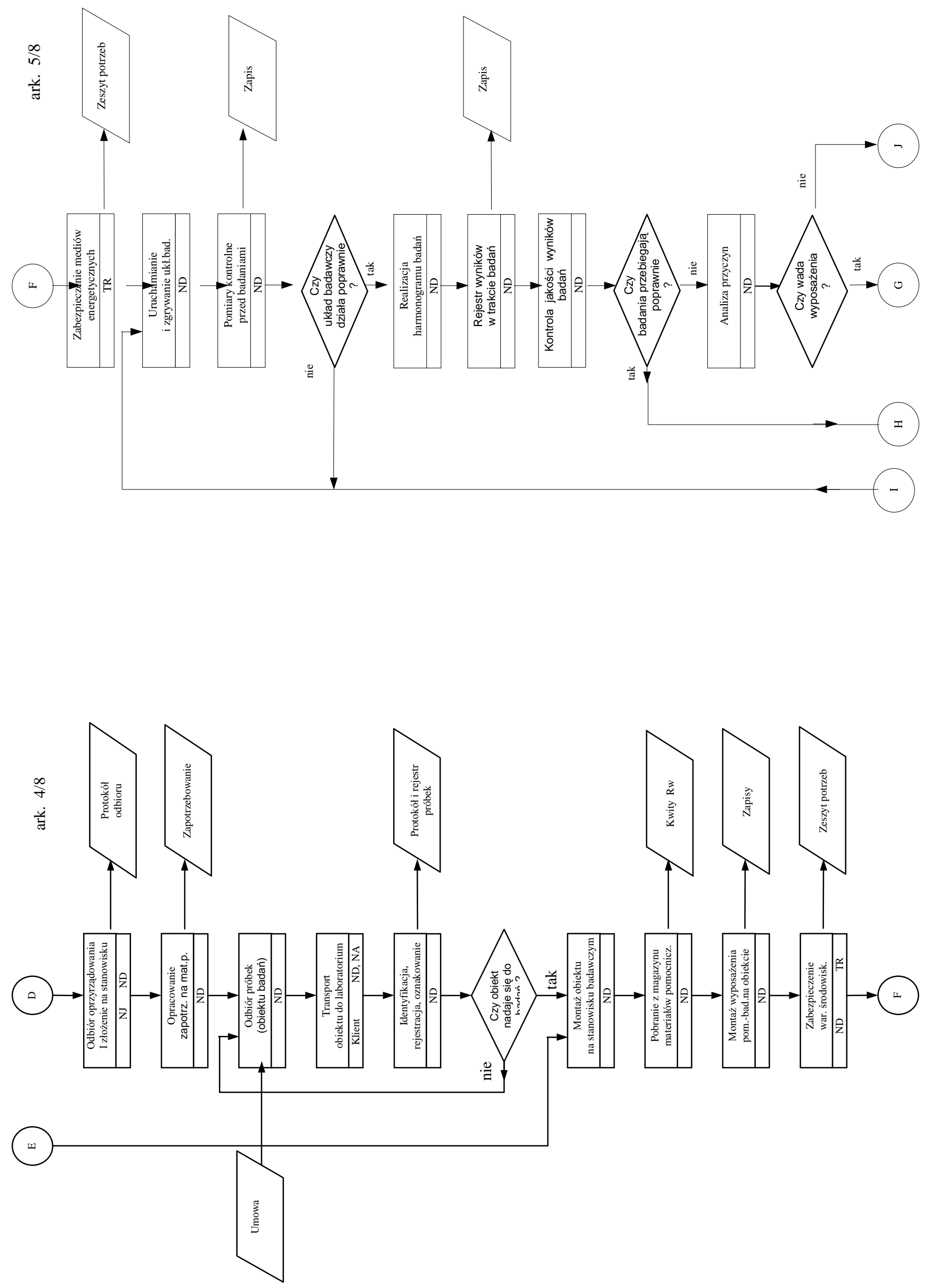

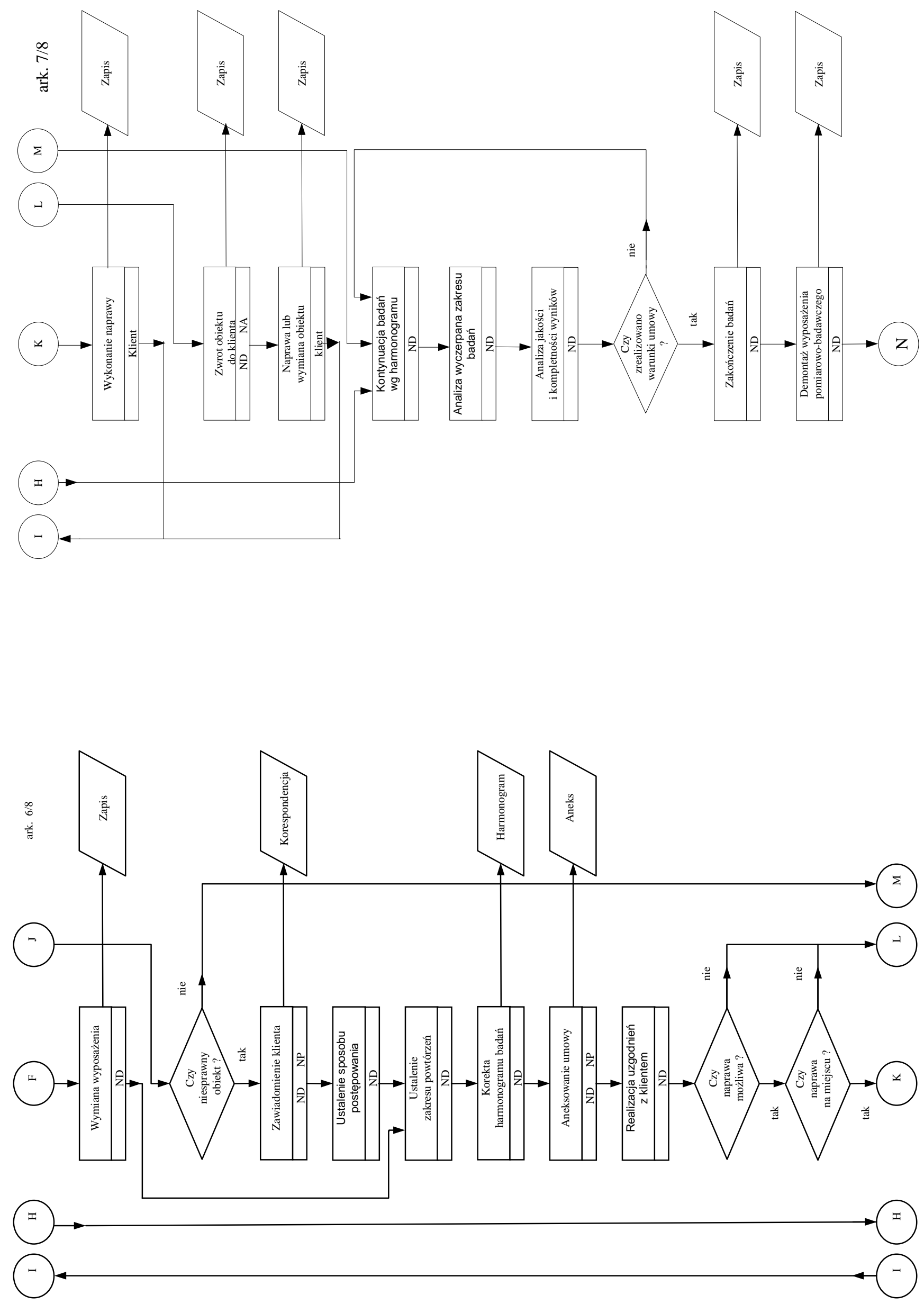


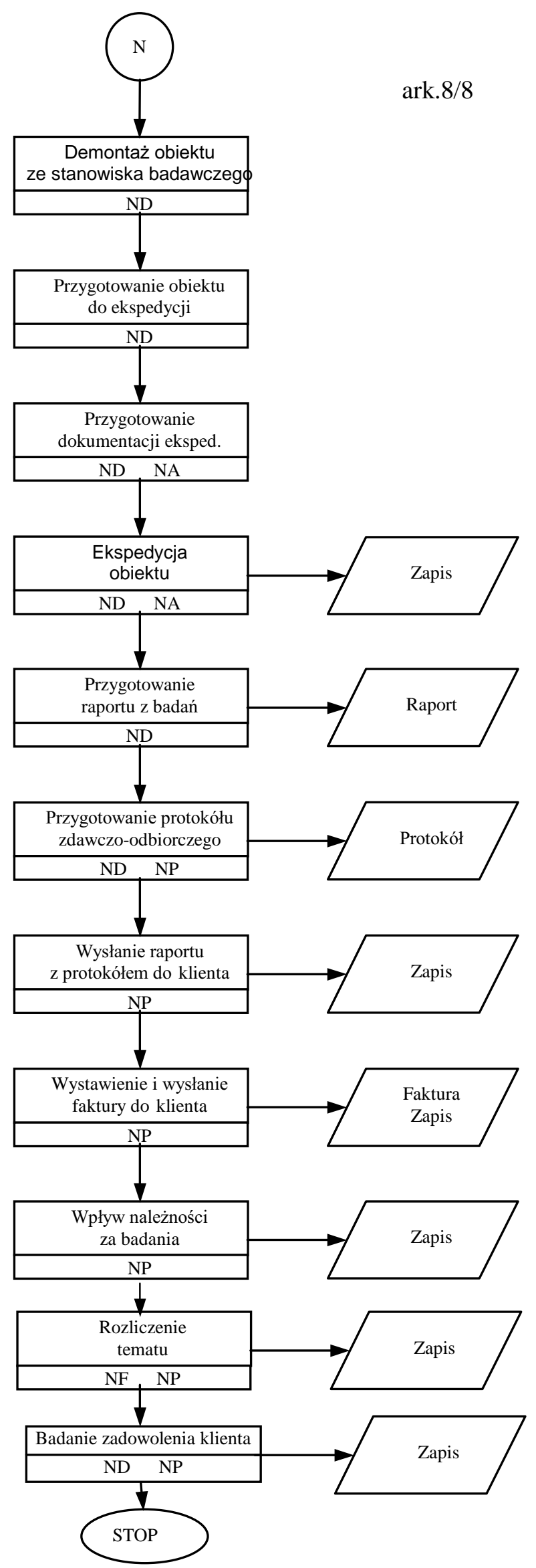

